Louisiana State University

LSU Digital Commons

Faculty Publications

Department of Biological Sciences

$1-1-2005$

\title{
Mitochondrial variation in Bolivian populations of the Variable Antshrike (Thamnophilus caerulescens)
}

Robb T. Brumfield

University of Washington, Seattle

Follow this and additional works at: https://digitalcommons.Isu.edu/biosci_pubs

\section{Recommended Citation}

Brumfield, R. (2005). Mitochondrial variation in Bolivian populations of the Variable Antshrike (Thamnophilus caerulescens). Auk, 122 (2), 414-432. https://doi.org/10.1642/

0004-8038(2005)122[0414:MVIBPO]2.0.C0;2

This Article is brought to you for free and open access by the Department of Biological Sciences at LSU Digital Commons. It has been accepted for inclusion in Faculty Publications by an authorized administrator of LSU Digital Commons. For more information, please contact ir@lsu.edu. 
The Auk 122(2):414-432, 2005

(C) The American Ornithologists' Union, 2005.

Printed in USA.

\title{
MITOCHONDRIAL VARIATION IN BOLIVIAN POPULATIONS OF THE VARIABLE ANTSHRIKE (THAMNOPHILUS CAERULESCENS)
}

\author{
Robi T. Brumfield ${ }^{1}$ \\ Department of Biology, University of Washington, Seattle, Washington 98195, USA
}

\begin{abstract}
Aвstract. - The Variable Antshrike (Thamnophilus caerulescens) is arguably the most polytypic thamnophilid, with males ranging from almost entirely jet black to nearly white. The four subspecies that occur in Bolivia are strikingly divergent in male plumage: T. c. aspersiventer (black with white-barred belly), T. c. connectens (black back and bib with white belly), T. c. dinellii (gray throat and back with rufous belly), and T. c. paraguayensis (light gray with white belly). To assess the genetic structure of those taxa in Bolivia, sequence variation at the mitochondrial cytochrome- $b$ gene was screened in 126 individuals collected across transects spanning the plumage and vocal variation in the four forms. A 95-km-wide cline in haplotype frequencies from T. c. aspersiventer to T. c. dinellii was centered in the Serrania Cochabamba across an ecotone from humid to dry Andean foothill habitats. Thamnophilus caerulescens connectens is not a valid taxon, instead representing an introgressed population near the dinellii tail of the T. c. aspersiventer-T. c. dinellii hybrid zone. Although direct contact between T. c. dinellii and T. c. paraguayensis remains undocumented, the mitochondrial data were consistent with introgression along a broad cline extending across most of southern Bolivia. Overall, the transitions in mitochondrial frequencies were remarkably concordant with clinal changes in vocalizations among those same populations (Isler et al. 2005). Both studies highlight the need for increased sampling, in both the geographic extent and number of individuals per population, to address adequately the potential for clinal variation between populations that are not isolated geographically. A more restricted sampling design in the present study might have led to the erroneous conclusion that T. c. aspersiventer, T. c. dinellii, and T. c. paraguayensis have reciprocally monphyletic mitochondrial lineages, making them full species according to some species concepts. Received 5 February 2004, accepted 29 November 2004.
\end{abstract}

Key words: clinal variation, hybrid zone, speciation, systematics, Thamnophilidae, Thamnophilus caerulescens, Variable Antshrike.

Variación Mitocondrial en Poblaciones Bolivianas de Thamnophilus caerulescens

Resumen. - Thamnophilus caerulescens es probablemente el tamnofílido más polítipico, considerando que los machos varían en coloración desde casi completamente negra hasta casi blanca. Las cuatro subespecies que se encuentran en Bolivia varían de forma llamativa en términos del plumaje de los machos: T. c. aspersiventer (negro con el vientre barreteado con blanco), T. c. connectens (espalda y babero negros con vientre blanco), T. c. dinellii (garganta y espalda grises con vientre rufo), y T. c. paraguayensis (gris claro con vientre blanco). Para determinar la estructura genética de estos taxa en Bolivia, se examinó la variación en secuencias del gen mitocondrial citocromo- $b$ en 126 individuos colectados a través de transectos que cubrían la variación en

\footnotetext{
${ }^{1}$ Present address: Museum of Natural Science, 119 Foster Hall, Louisiana State University, Baton Rouge,
} Louisiana 70803, USA. E-mail: brumfld@lsu.edu 
plumaje y vocalizaciones existente entre las cuatro formas. Una clina en la frecuencia de haplotipos de T. c. aspersiventer a T. c. dinellii de $95 \mathrm{~km}$ de ancho estuvo centrada en la Serranía Cochabamba, a través de un ecotono entre hábitats húmedos y secos en el piedemonte andino. Thamnophilus caerulescens connectens no es un taxón válido; en cambio, representa una población en la que ha sucedido introgresión cerca del extremo dinelli de la zona de hibridación entre T. c. aspersiventer y T. c. dinellii. Aunque aún no se ha documentado contacto directo entre T. c. dinellii y T. c. paraguayensis, los datos mitocondriales son consecuentes con la ocurrencia de introgresión a lo largo de una clina amplia que se extiende a través de buena parte del sur de Bolivia. En general, las transiciones en las frecuencias mitocondriales fueron notablemente concordantes con cambios clinales en las vocalizaciones entre las mismas poblaciones (Isler et al. 2005). Ambos estudios destacan la necesidad de tener muestreos amplios tanto en términos del ámbito geográfico como del número de individuos por población para examinar adecuadamente la posibilidad de que existan variaciones clinales entre poblaciones que no están aisladas geográficamente. Un diseño de muestreo más restringido que el empleado en este estudio podría haber llevado a la conclusión errónea de que T. c. aspersiventer, T. c. dinellii y T. c. paraguayensis representan linajes mitocondriales recíprocamente monofiléticos, lo que a la luz de algunos conceptos de especie sería considerado evidencia para tratarlos como especies distintas.

HYBRID zONES HAVE long played an important role in speciation analysis (Mayr 1942, Zink and Remsen 1986), because they provide a natural venue in which the reproductive isolation of divergent populations can be assessed. Nearly all hybrid zones, particularly in vertebrates, are interpreted in terms of secondary contact (Moore 1977). Although primary differentiation via selection along a gradient could produce a similar pattern (May et al. 1975, Navarro and Barton 2003), there is still little data consistent with selection-generated gradients, especially in birds (but see Smith et al. 1997). The outcome of secondary contact is influenced by the amount of prezygotic and postzygotic isolation; the former is determined primarily by the amount of divergent evolution in mate recognition and secondary sexual traits (Lande 1981), the latter by the amount of genome-wide divergence (Haldane 1922, Noor 1999). In addition to reinforcement (Noor 1999) and reticulation, a possible outcome of secondary contact is the formation of a stable cline, the equilibrium of which is maintained by a balance between the reduced average fitness of hybrids and the dispersal of parentals into the zone (Key 1968). Such tension zones are capable of moving away from the point of initial contact (Barton and Gale 1993), usually ending up in a region where the amount of dispersal into the zone is equivalent for the two parental forms; that is why such zones are often positioned at ecotones (Moore 1977, Moore and Price 1993).
The Variable Antshrike (Thamnophilus caerulescens) is arguably the most polytypic thamnophilid (Zimmer and Isler 2003), with male plumage variation ranging from almost entirely jet black to nearly white. Females also differ in plumage among subspecies, but to a much lesser extent than males. Thamnophilus caerulescens consists of 12 subspecies that replace each other along a long arc encompassing the foothills of the Eastern Andean Cordillera from the Marañon Valley of northern Peru south to northern Argentina, and thence eastward into lowland chaco (southeastern Bolivia, Paraguay, northern Argentina), cerrado (southeastern Paraguay, northeastern Argentina, southern Brazil), Atlantic Forest (southeastern Brazil, Uruguay), and disjunctly in the caatinga of northeastern Brazil (Peters 1951, Short 1975, Remsen and Traylor 1989, Darrieu 1997). Except that some subspecies of T. caerulescens also occur in humid montane forest, its distribution is similar to the Eastern Brazilian-Andean pattern shared by a number of bird species restricted to dry lowland and montane habitats (Silva 1995, García-Moreno et al. 1999).

In Bolivia, four subspecies of T. caerulescens occur that differ strikingly in male plumage color. Thamnophilus caerulescens aspersiventer males are jet black with varying amounts of white barring in their belly feathers. That taxon occurs in humid and semihumid foothill forests (around 1,500-2,500 $\mathrm{m}$ above sea level) of the 
Eastern Cordillera in Bolivia, from the Peruvian border south to the north slope of the Serrania Cochabamba in the department of Cochabamba. The Serrania continues southeastward into Santa Cruz, but T. c. aspersiventer is unknown from that department (Bond and Meyer de Schauensee 1942, contra Zimmer and Isler 2003), resulting in a distributional gap between the southeasternmost occurrence of T. c. aspersiventer near Villa Tunari (in Cochabamba; S. Herzog pers. comm.) and T. c. connectens, a relatively small population of T. c. aspersiventerT. c. dinellii intergrades on the southern slope of the divide in Santa Cruz (Fig. 1A; Cory and Hellmayr 1924). It is unclear whether the gap between T. c. aspersiventer and T. c. connectens is real or simply represents the little ornithological exploration of the region (Remsen and Traylor 1989, Paynter 1992).

Plumage variation in male $T$. c. connectens ranges from black-backed birds with black pectoral bibs and entirely white bellies to males that are indistinguishable from T. c. dinellii, a subspecies that replaces T. c. connectens to the west in higher-elevation forests and interAndean valleys, and to the south in semihumid Tucumano-Boliviano and dry boreal chaco forest (Fig. 1A; Darrieu and Camperi 1990, Schmitt et al. 1997, Schulenberg and Awbrey 1998, Mayer 2000, Mayer et al. 2000, Navarro 2002). Male T. c. dinellii have dark gray backs, light gray throats, and rufous bellies. In Bolivia, T. c. dinellii is restricted to the Andean foothills (around 875-2,500 $\mathrm{m}$ above sea level); but in northern Argentina, its distribution extends eastward into the lowland chaco, to the Río Pilcomayo (Darrieu 1997). The fourth subspecies found in Bolivia, T.c. paraguayensis, is found in the lowland chaco of southeastern Bolivia, Paraguay, and southern Brazil (Short 1975, Kratter et al. 1993, Parker et al. 1993). Males have light gray backs and chests and grayish white bellies. Contact between T. c. dinellii and T. c. paraguayensis in Bolivia and Argentina is undocumented.

Here, I characterize the variation in mitochondrial DNA in Bolivian populations of $T$. caerulescens. In its Bolivian range, $T$. caerulescens is often among the most common forest and forest-edge birds. Nonetheless, genetic variation within or among those populations has never been characterized. I use a mitochondrial gene tree to establish whether the Bolivian subspecies represent distinct, reciprocally monophyletic, mitochondrial lineages. I characterize transitions in mitochondrial haplotype frequency across the contact zones. A companion study by Isler et al. (2005) examines vocal characters in some of the same populations to assess taxonomic limits.

\section{Methods}

\section{SAMPLES}

During June-August 2000 and April-May 2002, birds were collected with shotgun or mist net along a transect in the Bolivian Eastern Cordillera spanning the plumage variation from T. c. aspersiventer, through T. c. connectens, to T. c. dinellii. Samples of T. c. paraguayensis were collected in the Bolivian lowland chaco (Fig. 1, Table 1, and Appendix). When possible, a bird's vocalizations were tape-recorded before collection (Isler et al. 2005). An effort was made to collect at least one population sample as close as possible to the type localities of each taxon. The aspersiventer samples were collected in Yungas forest in Cochabamba (Table 1), but how close that was to the type locality is uncertain. The type locality of "Yungas Bolivia" is a vague reference to the humid foothill forests that characterize the Eastern Andes of departments La Paz and Cochabamba (Peters 1951). One of the population samples of T. c. connectens (C2) was collected $\sim 23 \mathrm{~km}$ east of its type locality, in Samaipata (Fig. 1B). Neither the type locality of T. c. dinellii in northern Argentina (Estancia Isca Yacu, province Santiago del Estero) nor that of T. c. paraguayensis in Paraguay (Río Apa, department of Concepción) was sampled. All specimens were prepared as study skins with an accompanying spread wing and partial skeleton. Samples of breast muscle, heart, and liver were placed in a single cryotube and preserved in liquid nitrogen within $6 \mathrm{~h}$ after birds were sacrificed. Specimens were deposited in the collections of the Burke Museum of Natural History (UWBM, Seattle, Washington), the Louisiana State University Museum of Zoology (LSUMZ, Baton Rouge), or the Museo de Historia Natural Noel Kempff Mercado (MNKM, Santa Cruz, Bolivia). To serve as outgroups in the phylogenetic analysis, individuals of T. unicolor (LSUMZ B12144) and T. aethiops (LSUMZ B14649) were sequenced. 

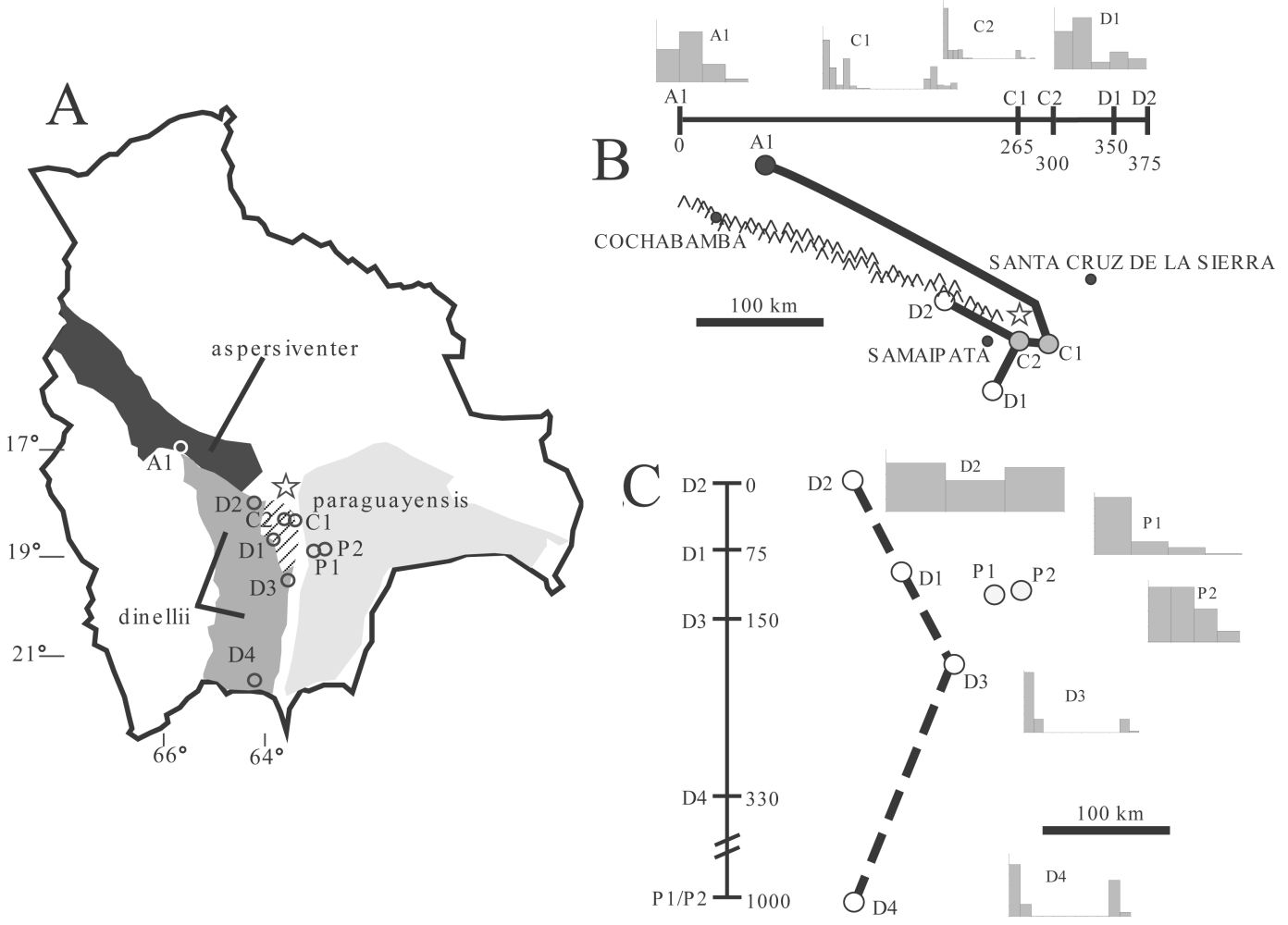

FIG. 1. Schematic distribution of T. caerulescens in Bolivia. (A) Population samples collected for the present study are indicated by a circle; codes refer to localities in Table 1. Distribution of $T$. c. aspersiventer is highlighted in black, T. c. connectens in hatched black and white, T. c. dinellii in dark gray, and T. c. paraguayensis in light gray; star (also in Fig. 1B) indicates estimated center of $T$. c. aspersiventer-T. c. dinellii hybrid zone. (B) Distribution of samples and linear transformation of the transect spanning variation from T. c. aspersiventer to T. c. dinellii. (C) Distribution of samples and linear transformation of the transect spanning variation from T. c. dinellii to T. c. paraguayensis. Mismatch distributions are presented for each population sample, with number of absolute sequence differences on $x$ axis (beginning with 0 , in increments of 1 ), and population frequency on $y$ axis (beginning with 0 , in increments of 0.1 ). Railroad symbol between D4 and P1-P2 indicates break in linear scale.

Because of the complex topography of the region, the population samples that span the variation between $T$. c. aspersiventer and T. c. dinellii form a curvilinear transect, extending from the population sample of T. c. aspersiventer (A1) on the north side of the divide in Cochabamba to two population samples of T. c. connectens $(\mathrm{C} 1, \mathrm{C} 2)$ and two of $T$. c. dinellii (D1, D2) on the south side of the divide in Santa Cruz (Fig. 1). Those samples correspond, respectively, to populations $\mathrm{A}, \mathrm{C}$, and $\mathrm{DN}$ in Isler et al. (2005).

At the time the fieldwork for this study was conducted, intergradation between $T$. c. dinellii and T. c. paraguayensis was undocumented, and there is still only genetic evidence of introgression between the two (see below). On the basis of a posteriori knowledge of the mitochondrial frequency cline, which in Bolivia extends in a north-south axis along the foothills of the Eastern Andean Cordillera, a T. c. dinellii to T. c. paraguayensis transect begins at population $\mathrm{D} 2$ and extends southward to include populations D1, D3, and D4 (Table 1 and Fig. 1C). Population samples of T. c. paraguayensis (P1, P2) collected in the Bolivian lowland chaco (Fig. 1) serve as the parental samples of that subspecies. Samples D1 and D2 correspond to population 


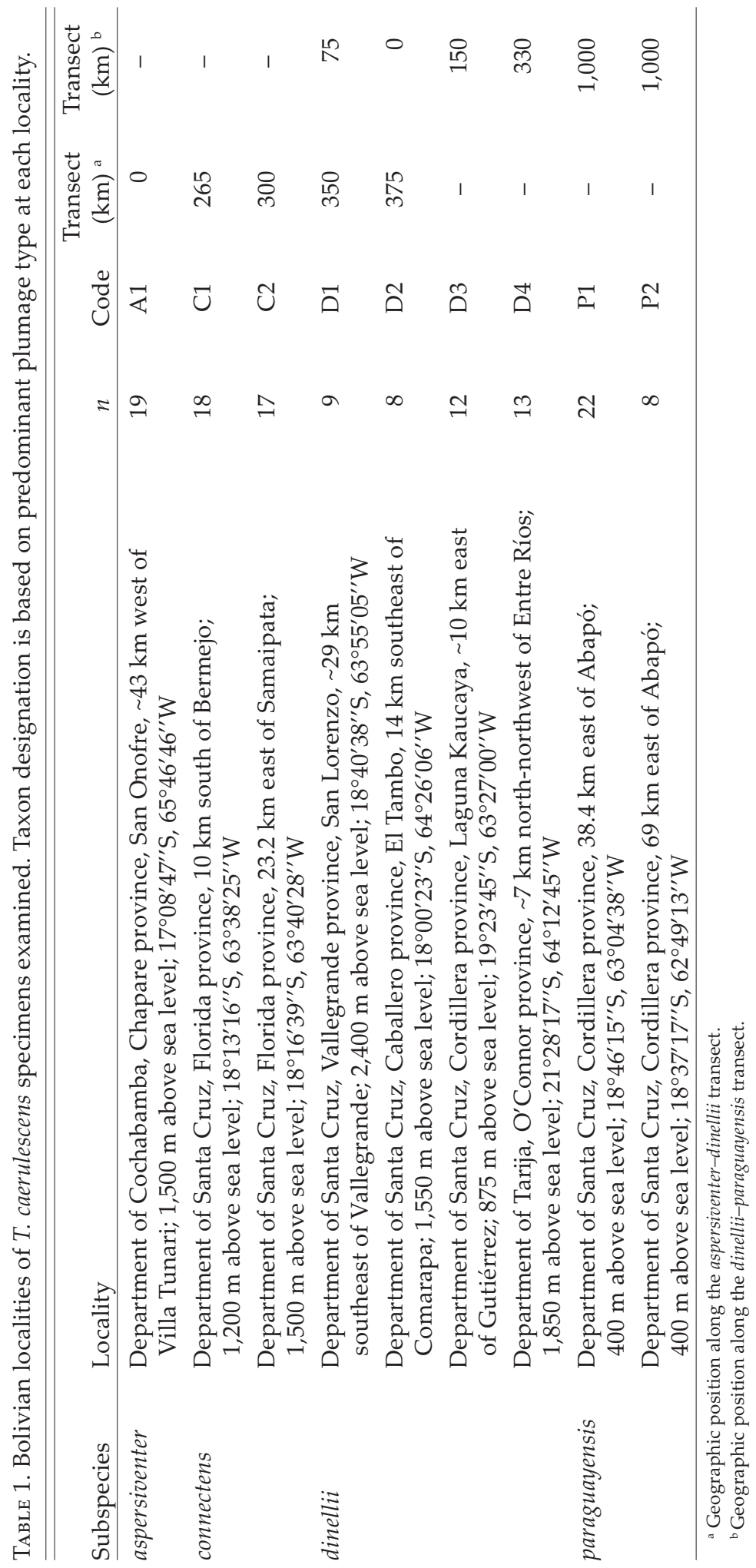


DN in Isler et al. (2005), and P1 and P2 to P. All other sample designations are identical in the two studies.

\section{Sequence Data}

Total DNA was extracted from $25 \mathrm{mg}$ of breast muscle using DNeasy spin columns (Qiagen, Valencia, California). The entire mitochondrial cytochrome- $b$ gene was amplified using the primers L14841 (CCATCCAACATCTCAG CATGATGAAA) and H16065 (AACTGCAGT CATCTCCGGTTTACAAGAC) (Kocher et al. 1989, Hackett 1996). Polymerase chain reaction amplification was performed in a PTC-100 or PTC-200 thermocycler (MJ Research, Waltham, Massachusetts) with the following conditions: $94^{\circ} \mathrm{C} 2 \mathrm{~min}, 35$ cycles of $94^{\circ} \mathrm{C} 30 \mathrm{~s}, 45^{\circ} \mathrm{C} 30 \mathrm{~s}$, $72^{\circ} \mathrm{C} 1 \mathrm{~min}$, and a final 5 -min extension at $72^{\circ} \mathrm{C}$. Reactions had a total volume of $25 \mu \mathrm{L}$ and contained $2.5 \mu \mathrm{L}$ of $10 \times$ buffer, $0.5 \mathrm{U}$ AmpliTaq (Applied Biosystems, Foster City, California), $200 \mu \mathrm{m}$ dNTPs (Applied Biosystems), $125 \mathrm{nmol}$ of each primer (Integrated DNA Technologies, Coralville, Iowa), and $\sim 50 \mathrm{ng}$ of template. Amplicons were purified by precipitating in PEG, washing with cold $80 \%$ ethanol, and resuspending in $12.5 \mu \mathrm{L} 10 \mathrm{mM}$ Tris- $\mathrm{HCl}, \mathrm{pH}$ 8.0. Cycle sequencing reactions had a total volume of $10 \mu \mathrm{L}$ and contained 1.6 $\mu \mathrm{L}$ Big Dye Terminator (version 1 or 2, Applied Biosystems), $0.32-0.40 \mu \mathrm{M}$ L14841 or H16065 primer, and $2.0 \mu \mathrm{L} 5 \times$ buffer $(400 \mathrm{mM}$ Tris- $\mathrm{HCl}, \mathrm{pH}$ 9.0; $10 \mathrm{mM} \mathrm{MgCl}_{2}$ ). Reactions were purified using either isopropanol or sodium acetate-ethanol precipitation, and loaded onto an ABI 377 automated sequencer. Contigs of the two sequences per individual were made using SEQUENCHER 4.1.2 (Gene Codes, Ann Arbor, Michigan).

\section{Data Analysis}

Multiple alignments were constructed using CLUSTALW (Higgins and Sharp 1988) and the alignment imported into PAUP*, version $4.0 \mathrm{~b} 10$ (Swofford 1998). From an initial neighborjoining (Saitou and Nei 1987) tree reconstructed from the raw percentage-sequence-divergence matrix, the best-fit maximum-likelihood (ML) model was determined using MODELTEST, version 3.06 (Posada and Crandall 1998). A neighbor-joining gene tree was subsequently reconstructed from the HKY85 (Hasegawa et al.
1985) pairwise distance matrix with no correction for rate heterogeneity. Confidence in nodes was assessed using 10,000 neighbor-joining bootstrap replicates. Maximum-parsimony and ML analyses were also performed. A minimum spanning network of haplotype relationships was constructed from a pairwise absolute nucleotide difference matrix using the program TCS, version 1.18 (Clement et al. 2000).

The program DNASP, version 3.14 (Rozas and Rozas 1999) was used to estimate the nucleotide diversity parameter $\pi$, a measure of the average number of nucleotide differences per site between two randomly chosen sequences, and $\Theta\left(2 N_{f}\right.$; Watterson 1975), a measure of the proportion of variable sites in each population sample. DNASP was also used to calculate the number of haplotypes and segregating sites $(S)$ in each population sample. As a test of selective neutrality, Tajima's (1989) D statistic was calculated and its significance assessed by comparison to a beta distribution. To infer the longterm demographic history of the populations, the $R 2$ statistic was calculated. That measure is based on the difference between the number of singleton mutations and the average number of nucleotide differences among sequences within a population sample, and represents a better test than other measures when samples sizes are small (Ramos-Onsins and Rozas 2002). Significance of $R 2$ was evaluated by comparing the observed value with a null distribution of $R 2$ simulated under the coalescent, using the empirical population sample size and observed number of segregating sites. Demographic history was also tested, by plotting mismatch distributions for each population sample, with the assumption that stable populations have ragged distributions whereas exponentially growing populations have smooth Poisson distributions. The null hypothesis in this test is that the population has undergone an expansion, because there is no quantitative expectation for the shape of the mismatch distribution in a stationary population (Harpending 1994). Statistical significance was assessed with 5,000 bootstrap replicates using ARLEQUIN (Schneider et al. 2000).

The geographic structure of the genetic variation was tested using an analysis of molecular variance (AMOVA) implemented in ARLEQUIN (Schneider et al. 2000). In the first analysis, samples north and south of the 
continental divide in the T. c. aspersiventer-T. c. dinellii transect (Fig. 1B) were treated as groups. In a second analysis, samples of T. $c$. dinellii and T. c. paraguayensis were treated as groups (Fig. 1C). The null distribution was generated by calculating the variance parameters on each of 5,000 resampled data sets. To detect finerscale structure, $F_{S T}$ was calculated between all population samples. In addition, the effective migration rate $\left(2 N_{f} m\right)$ between populations was estimated using an ML-based Markov chain Monte Carlo methodology implemented in MIGRATE (Beerli and Felsenstein 2001; see Acknowledgments). To reduce the number of estimated parameters, symmetric migration rates were estimated instead of asymmetric rates. MIGRATE was run with 10 short chains of length 200,000 that were sampled every 20 trees, followed by three long chains of length 2 million that were sampled every 20 trees. After discarding the initial 10,000 burn-in trees, the final total number of trees used in the parameter estimation was 100,000 . The analysis was repeated $10 \times$ using different random seeds to gauge the stability of the results. Geographic distance and $F_{S T}$ matrices were tested for association (i.e. isolation by distance) by Mantel tests with 1,000 permutations.

To estimate the width and center position of the transition in mitochondrial frequencies across the T. c. aspersiventer-T. c. dinellii hybrid zone, an ML cline was fit to the data using ANALYSE (see Acknowledgments). The shape of a cline can be modeled by combining three mathematical expressions (Szymura and Barton 1986, 1991):

$$
\begin{aligned}
& e^{X\left(\text { decay }_{a}\right)} \text { intercept }_{a} \\
& \frac{1}{1+e^{-4 X}} \\
& 1-e^{-X\left(\text { decay }_{d}\right)} \text { intercept }_{d}
\end{aligned}
$$

where

$$
\begin{gathered}
\operatorname{decay}_{a}=2 \sqrt{\theta_{a}}, \\
\operatorname{decay}_{d}=2 \sqrt{\theta_{d}}, \\
\operatorname{intercept}_{a}=\frac{t_{d}}{t_{a}+t_{d}+t_{a} t_{d}},
\end{gathered}
$$

$$
\begin{gathered}
\text { intercept } t_{d}=\frac{t_{a}}{t_{a}+t_{d}+t_{a} t_{d}}, \\
t_{a}=B_{a} \text { decay }_{a}, \\
t_{d}=B_{d} \text { decay }_{d} \\
\text { and } X=\frac{x-c}{w}
\end{gathered}
$$

is the distance $X$ along the cline scaled in relation to the center and width. Expression (1B) is a sigmoid in the center, and Expressions (1A) and (1C) are exponential decay curves leading away from either side of the center. The change from the central curve (1B) to the exponential tails occurs at the point where the decay curves (1A and 1C) cross the sigmoidal curve (1B). That crossing point changes, depending on the parameters. Parameters $\theta_{a}$ and $\theta_{d}$ describe the rate of exponential decay, and $B_{a}$ and $B_{d}$ describe the size of the central barrier to gene flow (Szymura and Barton 1986). The width of the cline $(w)$ is defined as 1 /maximum slope, $c$ is the central position of the cline where $p_{\text {est }}=0.5$, and $x$ is the distance (kilometers) from population A1 or D2, depending on the hybrid zone being analyzed (Table 1). Two additional parameters, $p_{\min }$ and $p_{\max }$ represent the frequencies at the two ends of the cline, and are used by ANALYSE to scale $p_{\text {est }}$ :

$$
p_{\text {est' }}=p_{\text {min }}+p_{\text {est }}\left(p_{\max }-p_{\text {min }}\right)
$$

Calculation of the likelihood of a fitted cline assumes a binomial sampling distribution for the molecular genetic markers. For each population, the support or goodness-of-fit for a fitted cline is expressed as a log-likelihood and is calculated as:

$$
\ln L=n\left[p_{\mathrm{obs}}\left(\ln \frac{p_{\mathrm{obs}}}{p_{\mathrm{est}}}\right)+\left(1-p_{\mathrm{obs}}\right)\left(\ln \frac{1-p_{\mathrm{obs}}}{1-p_{\mathrm{est}}}\right)\right]
$$

where $n$ is number of haplotypes sampled in the population, $p_{\text {obs }}$ is observed frequency of the modeled haplotype, and $p_{\text {est }}$ is estimated frequency of the modeled haplotype based on Expression 1. The support for the entire fitted cline is the sum of the population log-likelihoods.

Model parameters were estimated by a bounded, directional search of the parameter 
space using the Metropolis-Hastings algorithm (Metropolis et al. 1953, Hastings 1970) implemented in ANALYSE. Thirty thousand iterations of the Metropolis-Hastings algorithm were run with 20 different starting points. Two-unit loglikelihood support values $\left(\ln L_{\max }-2\right)$, equivalent to $95 \%$ confidence intervals, were inferred for each cline by running the Metropolis-Hastings search an additional 3,000 iterations. End positions of the cline $\left(p_{\min }, p_{\max }\right)$ were fixed in the analysis to 0 and 1 , but center (c), width (w) and additional parameters that determine the shape of the stepped portion of the cline $\left(B_{a^{\prime}} \theta_{a^{\prime}} B_{d^{\prime}} \theta_{d}\right)$ were estimated (Brumfield et al. 2001). Although the sampling was not designed optimally to characterize the structure of the T. c. dinellii-T. c. paraguayensis contact zone (Fig. 1C), ANALYSE was also used to fit an ML cline to the mitochondrial frequencies (Table 1), thus providing a rough estimate of the center of the transition under the assumption of a north-south axis. Because samples of $T$. c. paraguayensis from a locality near the end of the transect were not available, the geographic location of the parental population of paraguayensis was arbitrarily set at $1,000 \mathrm{~km}$ to reflect the large distance between D4 and P1-P2 (Table 1 and Fig. 1A).

\section{Results}

\section{Genetic Variation}

A total of 925 base pairs (bp) of the mitochondrial cytochrome- $b$ gene was sequenced from $126 \mathrm{~T}$. caerulescens individuals plus the two outgroups T. unicolor and T. aethiops (Table $1)$. Because internal primers were not used, the entire cytochrome- $b$ gene was not sequenced. The $925 \mathrm{bp}$ analyzed represent unambiguous sequences corresponding to bases 15,068-15,992 in the chicken (Gallus gallus domesticus) genome (Desjardins and Morais 1990). None of the sequences had stop codons indicative of nonfunctional nuclear copies. The sequences have been deposited to GenBank (Accession numbers: AY962685-AY962812).

There were 27 unique haplotypes in the 126 T. caerulescens sequences (Fig. 2); 19 of the haplotypes were unique to individuals. Of the remaining eight haplotypes, four were detected in more than one population sample. Variation among the sequences occurred at 45 sites distributed more-or-less heterogeneously along the sequence. Each subspecies had one haplotype with substantially higher frequency than all other haplotypes (Fig. 2): aspersiventer (53\%), connectens $(66 \%)$, dinellii $(69 \%)$, paraguayensis (80\%). The same high-frequency haplotype was shared by connectens and dinellii.

Several measures of within-population genetic diversity were calculated (Table 2). Across all population samples, number of haplotypes ranged from 3 to 7 , number of segregating sites $(S)$ from 2 to 23 , nucleotide diversity measure $\Theta$ from 0.083 to 0.723 , and nucleotide diversity measure $\pi$ from 0.039 to 0.622 . Measures of $S, \Theta$, and $\pi$ were consistently highest in the two T. c. connectens populations $(\mathrm{C} 1, \mathrm{C} 2)$, both of which contained some (5.9-16.7\%) T. c. aspersiventer haplotypes, and in the two T. c. dinellii populations (D3, D4) that contained some $(8.3-23 \%)$ T. c. paraguayensis haplotypes (Table 2). Three population samples (C2, D3, P1) had significant Tajima's $D$ values. Those significant values should probably not be given too much weight, because the test assumes, among other things, that populations have not undergone any recent expansions or bottlenecks (Tajima 1989). A null hypothesis of population expansion was not rejected by any of the mismatch distribution tests (results not shown), a result that is more or less consistent with a visual inspection of the plots (Fig. 1B, C). Because mismatch distributions represent a conservative test, the $R 2$ statistic was used to assess historical demography (Ramos-Onsins and Rozas 2002). A significant value in the D3 population samples represents the only reasonably strong statistical support for a recent population expansion.

\section{Haplotype Relationships}

Excluding the outgroups, there were 45 variable sites, 28 of which were parsimonyinformative. The best-fit ML model inferred from MODELTEST (Posada and Crandall 1998) was the HKY substitution model $(t i / t v=11.0219$; $A=0.2717, C=0.3287, G=0.1309, T=0.2686$ ) with no correction for among-site rate variation. The outgroup-rooted neighbor-joining gene tree composed three major lineages of haplotypes that corresponded to the subspecies T. $c$. aspersiventer, T. c. dinellii, and T. c. paraguayensis (Fig. 3). On the tree, T. c. paraguayensis and T. c. dinellii were sister taxa, a relationship consistent 


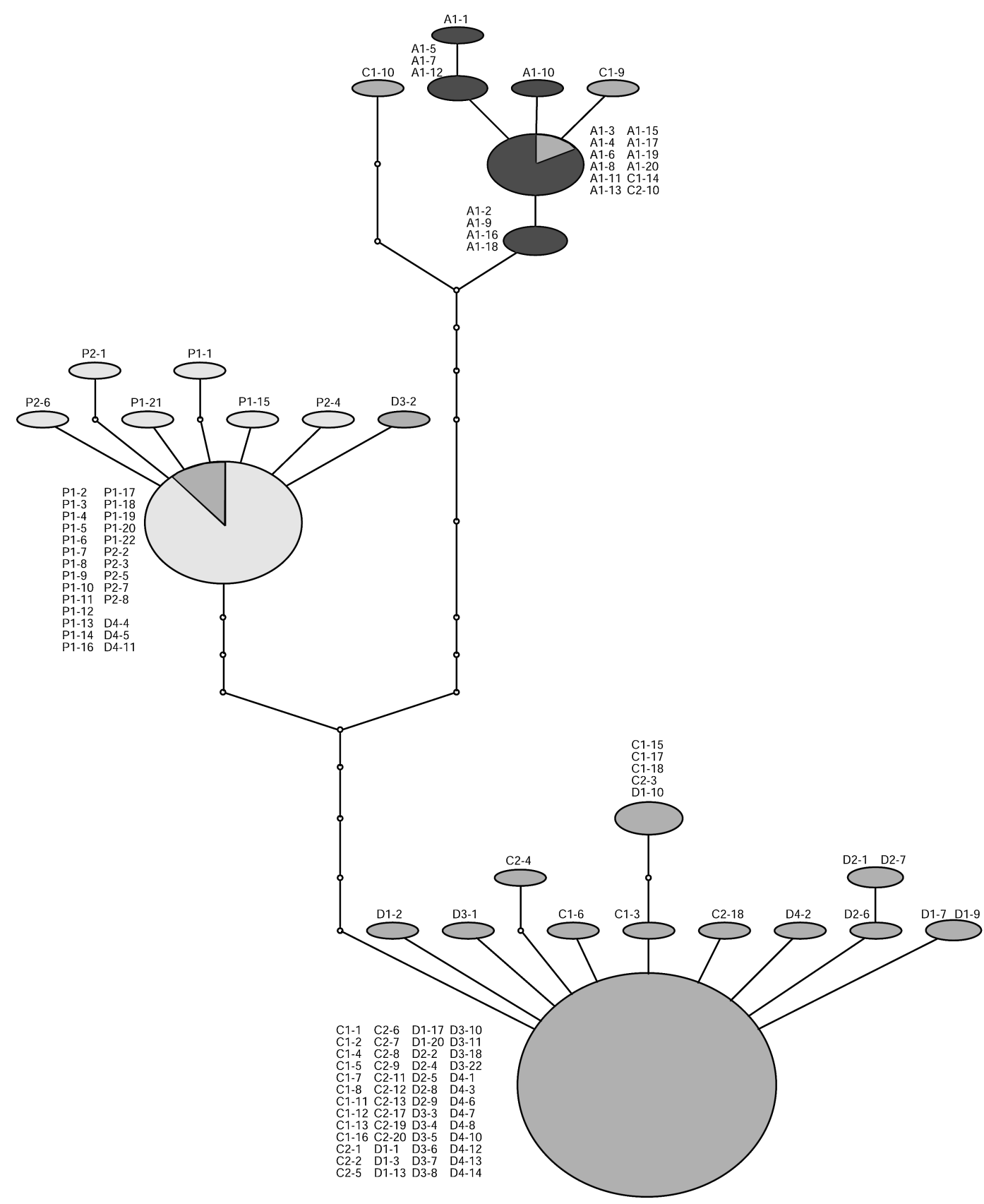

FIG. 2. Minimum spanning network of T. caerulescens haplotypes. Sample designations are given for all individuals; codes refer to localities in Table 1. Circle colors indicate the subspecies in which the haplotype was encountered (black, aspersiventer; dark gray, dinellii; light gray, paraguayensis). For cases in which a haplotype was detected in two subspecies, the frequency of its occurrence in each is depicted as a pie diagram. 


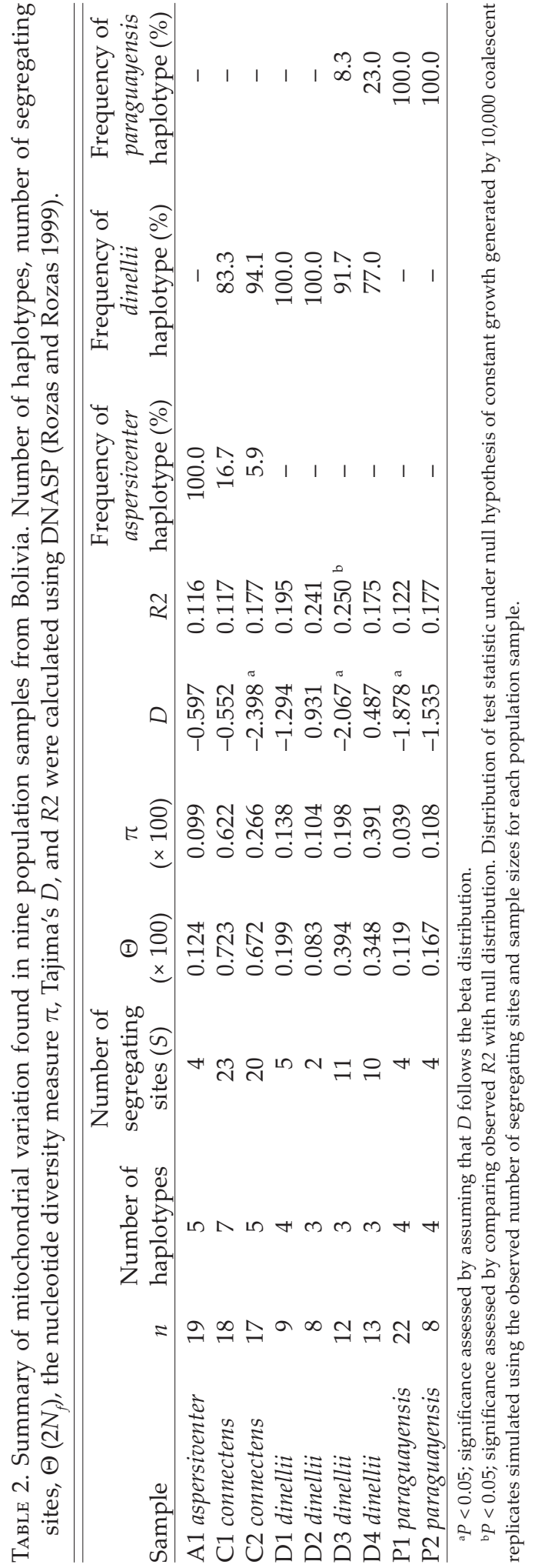

with a preliminary phylogeographic analysis of $T$. caerulescens samples from across its entire distribution (R. T. Brumfield unpubl. data). The three major clades had strong bootstrap support, but there was little support for most relationships within those clades. None of the three major clades was reciprocally monophyletic (Fig. 3), as evidenced by T. c. aspersiventer and T. c. dinellii haplotypes in the T. c. connectens populations, and T. c. paraguayensis haplotypes in two of the T. c. dinellii populations (D3, D4). A heuristic search with 10 random-addition replicates and tree-bisection-reconnection (TBR) branch-swapping under the equally weighted maximum-parsimony criterion resulted in a single most-parsimonious tree of 140 steps. The three strongly supported clades found in the neighbor-joining tree were recovered with at least $89 \%$ support in the parsimony analysis based on 100 nonparametric bootstrap replicates using the above search criteria (Fig. 3). A most likely tree $(-\ln L=2012.25)$ using the above likelihood model and parameters, TBR branch swapping, and the taxon addition "as-is" option had the same three strongly supported clades.

Average raw sequence divergence was low within the three major clades: $0.014 \pm 0.15 \%$ within the T. c. aspersiventer clade, $0.090 \pm 0.13 \%$ within T. c. dinellii, and $0.057 \pm 0.08 \%$ within the T. c. paraguayensis clade. The greatest levels of sequence divergence between haplotypes of the three taxa were $1.5 \%$ between $T$. c. dinellii (D1, D2) and T. c. paraguayensis (P1, P2), 1.9\% between T. c. aspersiventer (A1) and T. c. paraguayensis (P1, P2), and $2.2 \%$ between T. c. aspersiventer (A1) and T. c. dinellii (D1, D2).

Hybrid-zone Structure: Thamnophilus CAERULESCENS ASPERSIVENTER-THAMNOPHILUS CAERULESCENS DINELLII TRANSECT

It was not surprising to find both $T$. $c$. aspersiventer and T. c. dinellii haplotypes in the T. c. connectens population samples, because the intermediacy of male plumage characteristics in most T. c. connectens samples is consistent with intergradation between the two (Cory and Hellmayr 1924, Short 1975, Ridgely and Tudor 1994). No T. c. aspersiventer haplotypes were detected in the T. c. dinellii (D1-D4) population samples. Haplotypes from individuals C1-14 (male) and C2-10 (male) were identical to the most common A1 haplotype (Fig. 2), which is 

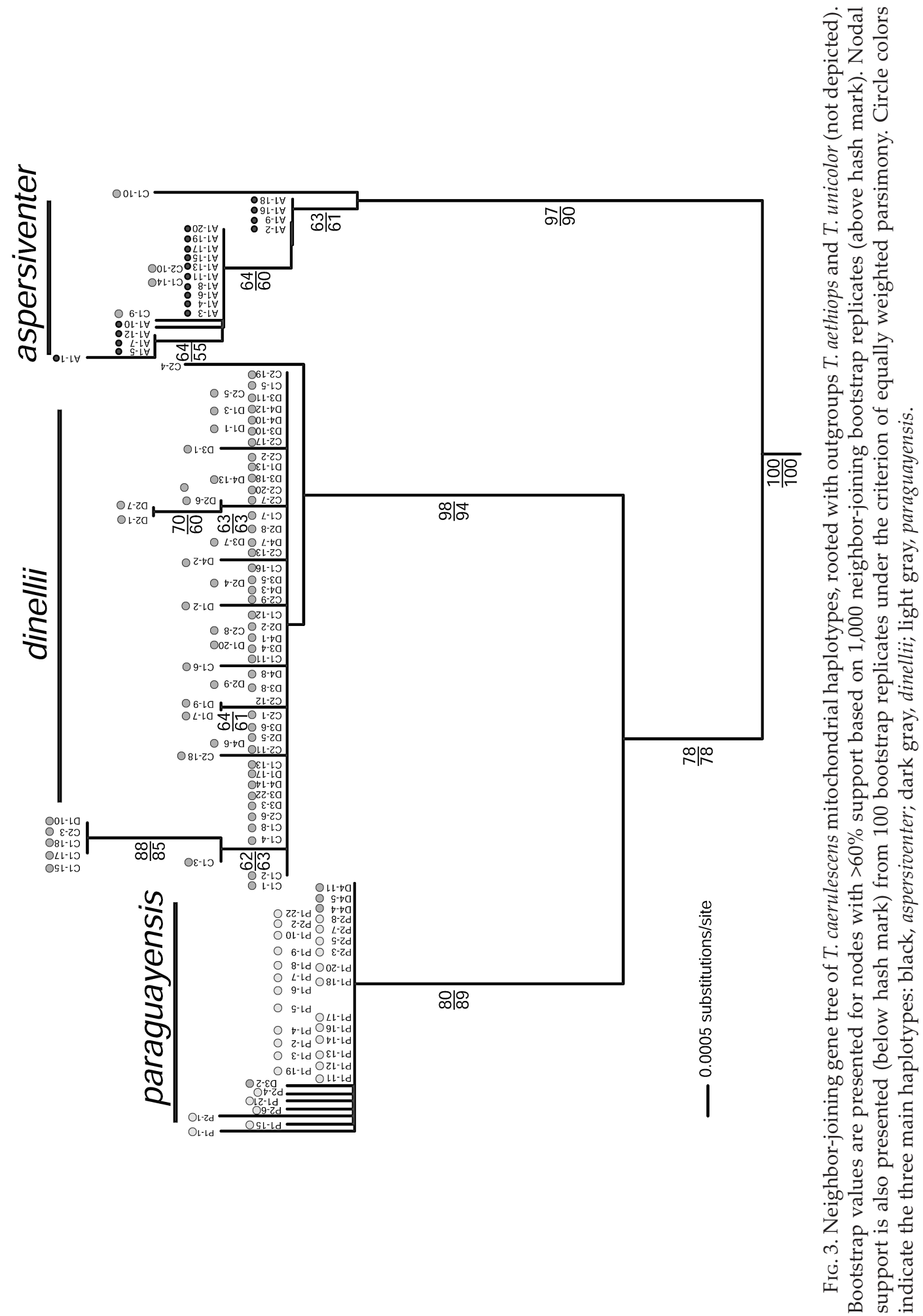
TAble 3. Pairwise estimates of $F_{S T}$ (below diagonal) and the effective number of migrants per generation ( $2 \mathrm{~N} m$, above diagonal).

\begin{tabular}{llllllllll}
\hline \hline & A1 & C1 & C2 & D1 & D2 & D3 & D4 & P1 & P2 \\
\hline A1 & - & 0.15 & 0.09 & 0.08 & 0.00 & 0.00 & 0.00 & 0.00 & 0.00 \\
C1 & 0.76 & - & 3.96 & 19.54 & 0.00 & 0.00 & 0.00 & 0.00 & 0.00 \\
C2 & 0.89 & 0.00 & - & 20.94 & 0.49 & 9.38 & 1.99 & 0.00 & 0.42 \\
D1 & 0.93 & 0.03 & -0.02 & - & 0.93 & 0.05 & 0.00 & 0.00 & 0.00 \\
D2 & 0.94 & 0.07 & 0.05 & 0.13 & - & 0.08 & 0.00 & 0.33 & 0.00 \\
D3 & 0.92 & 0.03 & -0.02 & 0.01 & 0.00 & - & 4.95 & 0.00 & 0.00 \\
D4 & 0.86 & 0.06 & 0.07 & 0.11 & 0.14 & 0.00 & - & 0.47 & 0.00 \\
P1 & 0.96 & 0.74 & 0.87 & 0.94 & 0.95 & 0.90 & 0.77 & - & 1.81 \\
P2 & 0.94 & 0.63 & 0.81 & 0.89 & 0.90 & 0.83 & 0.66 & 0.05 & - \\
\hline
\end{tabular}

consistent with ongoing or very recent introgression from population A1 into populations $\mathrm{C} 1$ and $\mathrm{C} 2$. The rest of the haplotypes from the two T. c. connectens population samples were indistinguishable or clearly derived from T. $c$. dinellii haplotypes that were common (>90\% frequency) in population samples D1 through D3.

A Mantel test revealed a significant $(P<0.05)$ association between geographic distance and $F_{S T}$ for population samples along the T. c. aspersiventer-T. c. dinellii transect, and the AMOVA detected significant genetic structure (Table 3). Along the T. c. aspersiventer-T. c. dinellii transect (Fig. 1B), $82 \%(P<0.05)$ of the variation was distributed between population samples north and south of the continental divide. Neither the genetic variation among population samples within groups $(0.9 \%)$ nor that within population samples $(17 \%)$ was significant. Based on the ML fitted cline $\left(\operatorname{lnL}=-0.112 ; p_{\min }=0 ; p_{\max }=1 ; B_{a}=\right.$ 145.1 [5.7-infinity]; $\theta_{a}=1.0$ [0.0-1.0]; $B_{d}=60.3$ [6.9-infinity]; $\theta_{d}=1.0$ [0.0-1.0]) from ANALYSE ( $95 \%$ confidence limits in brackets), the width of the mitochondrial cline was $95 \mathrm{~km}$ (confidence limits 33-239 km) and the center position of the cline was at $228 \mathrm{~km}$ (confidence limits 144$258 \mathrm{~km}$ ) along the transect (Fig. 1). That would place the most likely center of the cline in the eastern Andean foothills $\sim 40 \mathrm{~km}$ northwest of population sample C1 (see star in Fig. 1A, B). Additional sampling in that region would better define the structure of the cline and would help reduce the large confidence intervals on the cline shape parameters.

Maximum-likelihood estimates of the effective migration rate $(2 \mathrm{Nm})$ were largely consistent with a stepping-stone model of migration, with higher migration rates between adjacent populations (Table 3). Gene flow was highest between dinellii population D1 and the two connectens populations $\left(2 N_{f} m=19.5\right.$ and 20.9). Gene flow rates were relatively low between the remaining population samples.

Hybrid-zone Structure: Thamnophilus CAERULESCENS DINELLII-THAMNOPHILUS CAERULESCENS PARAGUAYENSIS TRANSECT

Encountering T. c. paraguayensis haplotypes in two of the four population samples of dinellii (D3 and D4) was unexpected, because males from all four T. c. dinellii population samples appeared to be typical of that subspecies, judging from plumage pattern (R. T. Brumfield unpubl. data). In addition, T. c. dinellii and T. c. paraguayensis are not known to be in contact. The shared haplotypes could reflect the retention of ancestral polymorphisms, introgression, or both processes (Pamilo and Nei 1988), but the restriction of the shared variation to the two southernmost population samples of T. c. dinellii is most consistent with introgression. The greater frequency of paraguayensis haplotypes in more-southern dinellii samples suggests a north-south or northwestsoutheast axis of mitochondrial introgression. The paraguayensis haplotypes found in the three D4 individuals (D4-4 female, D4-5 female, D4-11 male) were $0 \%$ divergent from most haplotypes in paraguayensis populations (P1, P2), thus supporting recent or ongoing intergradation with paraguayensis. The paraguayensis haplotype of the male (D3-2) from population D3 was $0.11 \%$ divergent from the most common haplotype in populations $\mathrm{P} 1$ and $\mathrm{P} 2$.

A significant $(P<0.05)$ association between geographic distance and $F_{S T}$ for population samples along the T. c. dinellii-T. c. paraguayensis transect was demonstrated by a Mantel test. 
An AMOVA detected significant genetic structure along the T. c. dinellii-T. c. paraguayensis transect, with $82 \%$ of the variation $(P<0.05)$ distributed between the two subspecies. The within-population variance component (16\%) was also significant.

The ML fitted cline $\left(\ln L=-0.426 ; p_{\min }=0\right.$; $p_{\max }=1 ; B_{a}=1,000.0[1,000$-infinity $] ; \theta_{a}=1.0$ $[0.0-1.0] ; B_{d}=1,000.0\left[1,000\right.$-infinity]; $\theta_{d}=0.0$ [0-1]) was $329(125-674) \mathrm{km}$ wide and was centered along the transect at $422 \mathrm{~km} \mathrm{(328-606}$ $\mathrm{km}), 92 \mathrm{~km}$ south of population sample D4. As expected with the limited geographic distribution of samples, the confidence limits on those estimates were large. Additional sampling along the contact zone would better define the genetic structure of this broad region of mitochondrial introgression.

\section{Discussion}

Subspecies of $T$. caerulescens in Bolivia that are strikingly divergent in male plumage color also exhibit mitochondrial divergence on the order of $1.5-2.2 \%$. None of the subspecies are reproductively isolated from each other. Introgression between T. c. aspersiventer and T. c. dinellii has long been evident, given the intermediacy of male plumage color traits in T. c. connectens (Cory and Hellmayr 1924, Short 1975), but the possible distributional gap between T. $c$. aspersiventer and T. c. connectens cast some doubt as to whether the morphological intermediacy of T. c. connectens reflected ongoing or past contact. The genetic data establish, minimally, that T. c. connectens is receiving immigrants with T. $c$. aspersiventer mitochondria. None of the males collected from localities $\mathrm{C} 1$ or $\mathrm{C} 2$ had T. c. aspersiventer-like plumage and most (83.3-94.1\%) had T. c. dinellii haplotypes. A likely interpretation that would explain the structure of these populations is that $T$. c. connectens represents the T. c. dinellii tail of a hybrid zone that extends across the continental divide to the northwest toward populations of pure T. c. aspersiventer (Bond and Meyer de Schauensee 1942). Future collecting in the region should uncover the genetic center of that transition zone, estimated to be $\sim 40 \mathrm{~km}$ northwest of population sample C1 (star in Fig. 1A, B).

The mitochondrial data also provided evidence for extensive introgression between T. c. dinellii and T. c. paraguayensis. That was somewhat unexpected, because although their distributions are in proximity to one another in Bolivia, contact is undocumented (Fig. 1). In the department of Santa Cruz, T. c. dinellii occurs in Andean foothill forest and boreal chaco (875-2,000 m; Navarro 2002), and it appears to be geographically isolated from $T$. c. paraguayensis in the lowland chaco east of the Andes (Kratter et al. 1993, Schmitt et al. 1997, Schulenberg and Awbrey 1998, Brumfield et al. 2004). Geographic isolation between the two in Bolivia may occur because of a narrow belt of lowland semi-deciduous forest (Velasco Forest) that runs parallel to the easternmost Andean slope along a north-south axis into northern Argentina (Herzog and Kessler 2002). Thamnophilus caerulescens is absent from that belt (R. T. Brumfield pers. obs.), though it apparently occurs in the larger stands of Velasco Forest east of the city of Santa Cruz de la Sierra (Parker et al. 1993).

The level of introgression between T. $c$. dinellii and T. c. paraguayensis is highest in the southernmost Bolivian population samples. Moving south from the northernmost population samples of T. c. dinellii (Fig. 1C), D1 and D2 showed no evidence of introgression, $8 \%$ of the haplotypes in population D3 were paraguayensis haplotypes, and $23 \%$ of the haplotypes in population D4 were paraguayensis haplotypes (Table 2). If introgression were occurring primarily along a west-east axis in Bolivia from the Andes to the lowland chaco, as was anticipated during the fieldwork for the present study, more paraguayensis haplotypes should have been detected in population sample D3 (elevation $875 \mathrm{~m}$ ) than in D4 (elevation 1,850 m). Defining the primary axis of the transition will remain problematic until additional samples are collected and analyzed, but a possible northwest-southeast axis is suggested by the river-limited distributions of T. c. dinellii and T. c. paraguayensis on opposite banks of the Río Pilcomayo along the Argentina-Paraguay border. Contact along the upper reaches of the Río Pilcomayo would be consistent with the decreased introgression moving northward in Bolivia.

\section{Vocalizations}

In light of the mitochondrial data, the clinal variation in vocalizations detected by Isler et al. (2005) can clearly be attributed to introgression. 
The concordance between the transitions in vocal characters and mitochondrial frequencies was remarkable (Isler et al. 2005) and corroborated the value of vocalizations in assessing species limits in antbirds (Isler et al. 1998). In some cases, the mitochondrial and vocal analyses were not fully comparable, because the vocal analysis (1) increased its sample size by lumping some population samples (e.g. C1 and C2) from the mitochondrial study and (2) included individuals not included in the genetic analysis. Nevertheless, similarities between the two were readily apparent. From T. c. aspersiventer to T. c. dinellii, $76-93 \%$ of the variation in six loudsong-pace vocal characters occurred from T. $c$. aspersiventer to T. c. connectens. Along the same transect, $83-94 \%$ of the transition in mitochondrial frequencies occurred from T. c. aspersiventer to T. c. dinellii.

\section{BiogeOgRAPHY}

The Serrania Cochabamba forms the distributional limit of a number of Andean taxa, including the southern limit of T. c. aspersiventer and the northern limit of T. c. dinellii (Remsen and Traylor 1989). Schulenberg et al. (1998) characterized the habitats on either side of the divide as "probably the most dramatic shift in flora and vegetation anywhere along the entire eastern slope of the Andes." The shift is attributable in part to large differences in mean precipitation. The southeastern tradewinds that carry moisture-laden Amazonian air to the northeast slope of the divide do so to a much lesser extent south of the divide, because of the bend in the Andes from a northwest-southeast axis to a more north-south axis (García 1994). South of the divide, humid Yungas forests are restricted to the few peaks of sufficient elevation $(>1,500 \mathrm{~m})$ to be enveloped in clouds year round (Schulenberg and Awbrey 1998). The rest of the habitat south of the divide forms a mosaic of semi-humid Tucumano-Bolivano forest and chaco scrub in the mountains, and dry thorn forest and scrub in the inter-Andean valleys (Killeen et al. 1993, Navarro 2002).

As with most hybrid zones, elucidating the history of the T. c. aspersiventer-T. c. dinellii hybrid zone is difficult. That the hybrid zone between them is centered along the ecological transition from humid montane forest on the north slope to drier habitats on the south slope suggests that this ecotone has influenced the genetic structure of the zone (Killeen et al. 1993, Rivera et al. 1996). Unfortunately, the two most commonly cited mechanisms of hybrid-zone formation, primary differentiation and secondary intergradation, make similar predictions about the resulting hybrid-zone structure. Primary differentiation along ecological gradients has received recent attention in the literature as a mechanism of diversification (Smith et al. 1997, 2001; Schneider et al. 1999; Aleixo 2002a). Secondary contact would predict, however, the same centering of the T. c. aspersiventer-T. c. dinellii hybrid zone on the ecotone across the divide. Many hybrid zones are thought to be maintained by a balance between selection acting to remove introgressed individuals from the zone, and dispersal of non-introgressed, pure parental forms into the zone. If the selective force acting against introgressed individuals is environmental (e.g. an ecological transition zone), then the zone is expected to track the ecotone (May et al. 1975, Moore and Price 1993). If the selective force is endogenous (e.g. genetic incompatibilities between the introgressed genomes), then the zone is expected to move to an equilibrium point at which the dispersal rate of the two taxa into the zone is equivalent. That point is usually at an ecotone (Hewitt 1988).

A very rough estimate of the divergence time between T. c. aspersiventer and T. c. dinellii can be inferred from the $1.6 \%$ (Fleischer et al. 1998) to $2 \%$ (Shields and Wilson 1987) sequence divergence per-million-years calibrations, which would place their divergence on the order of approximately 1.1 to 1.4 mya. Reconstructing the historical distribution of habitat in the region is complicated by the extensive habitat degradation associated with agriculture and fire, but primarily by the paucity of research on paleovegetation and paleoclimates of the Bolivian Andes (Graham et al. 2001). The elevation of the Andes along the divide has changed little over the past 2 million years, but the distribution of plant species and habitats has undoubtedly cycled with climatic changes (Gregory-Wodzicki 2000, Graham et al. 2001). The humid versus dry ecological requirements of T. c. aspersiventer and T. c. dinellii would make any historical separation of those habitats a reproductive barrier. Current contact between the two was facilitated along the eastern edge 
of the divide where the humid and dry habitats interdigitate (Killeen et al. 1993). Dry montane habitats occur patchily north of the divide (Herzog et al. 1997, Herzog and Kessler 2002), and humid habitats occur patchily south of the divide (Killeen et al. 1993), but the habitat isolating the patches makes current colonization unlikely.

The ecological transition from dry Andean habitats to lowland chaco appears less pronounced than that across the Serrania Cochabamba divide. Nevertheless, that transition, as well as the heterogeneity of dry habitats in southern Bolivia, and possibly also the Río Pilcomayo, are affecting the structure of the T. c. dinellii-T. c. paraguayensis hybrid zone. Assuming an allopatric model of divergence, the diversification of the two apparently occurred at a time when lowland chaco was isolated from montane dry habitats.

It is worth noting that $T$. caerulescens, one of the few thamnophilids that occurs in dry habitats (Ridgely and Tudor 1994), has relatively low levels of among-population genetic differentiation. Low levels of among-population genetic differentiation were also uncovered in an analysis of 10 dry-habitat avian species in Brazil (Bates et al. 2003), a pattern that contrasts dramatically with the relatively large levels of among-population genetic differentiation found in bird species of lowland wet forest (Capparella 1988; Brumfield and Capparella 1996; Bates et al. 1999; Bates 2000, 2002; Aleixo 2002b). Only additional sampling will determine whether that pattern is general to bird populations of South America.

\section{Sampling in Speciation Studies}

With a limited number of populationlevel genetic studies of Neotropical birds (e.g. Capparella 1988, 1991; Brumfield and Capparella 1996; Bates et al. 1999, 2003; GarcíaMoreno and Fjeldså 1999; García-Moreno et al. 1999, 2001; Bates 2000, 2002; Marks et al. 2002), and even fewer well-characterized Neotropical avian hybrid zones (e.g. Parsons et al. 1993, Brumfield et al. 2001), the first glimpses into the genetic structure of lowland Neotropical bird populations are being revealed. These data will obviously play a critical role in guiding taxonomic decisions, but it is crucial that the levels of genetic divergence and the patterns of genetic variation be considered in light of the (1) number and (2) geographic spacing of samples in the analysis. The genetic analysis of T. caerulescens illustrates that both aspects of sampling can greatly influence the geographic pattern of genetic variation and subsequent taxonomic interpretation of that pattern. That point is explored with the mitochondrial data from T. caerulescens.

Basic characterization of the levels and patterns of genetic variation in Bolivian subspecies of $T$. caerulescens would require, minimally, samples of the three subspecies (the fourth, T. c. connectens, was already presumed to be an intergrade), preferably from the type localities of each. For samples in the present study, the sampling design closest to meeting that criterion would include populations A1 (aspersiventer; $n=19$ ), D4 (dinellii; $n=13$ ), and P2 $(n=8)$, because those fall closest to the type localities. In the full analysis that included all samples from all populations, none of the three major mitochondrial clades of $T$. caerulescens was reciprocally monophyletic (Fig. 2). A limited analysis of samples from A1, D4, and P2 would have produced a tree in which A1 was monophyletic, but in which D4 and P2 were not. That would support treating T. $c$. aspersiventer as specifically distinct under some species concepts, despite the fact that it and $T$. c. dinellii appear to exchange genes extensively along their contact zone.

Only three of the 13 T. c. dinellii (D4) individuals in the limited analysis had the T. c. paraguayensis haplotype (Table 2). Had those individuals not been sampled, the mitochondrial data in the limited analysis would support reciprocal monophyly of all three subspecies. Assuming that the true frequency of $T$. c. paraguayensis haplotypes in population D4 is $23 \%$, detecting a single T. c. paraguayensis haplotype with $90 \%$ confidence would require a sample size of nine individuals. Increasing the confidence to $95 \%$ would require a sample of 12 individuals. Although many of the coalescent methods for estimating population genetic parameters require many fewer population samples than were needed for earlier noncoalescent methods based on estimates of population allele frequencies, the detection of rare haplotypes and alleles still requires relatively large sample sizes. That is especially true for population studies seeking to address species limits. 


\section{ACKNOWLEDGMENTS}

For logistical and permit assistance in Bolivia, I am indebted to S. Davis, A. Castillo, E. Guzmán, P. Rebolledo, R. A. Vespa, A. M. Saavedra, S. Herzog, A. B. Hennessey, S. Kreft, and S. Mayer. The following people helped collect or prepare antshrikes during fieldwork in Bolivia: M. J. Babin, R. C. Faucett, C. Gordon, O. Maillard Z., V. G. Rohwer, A. M. Saavedra, C. G. Schmitt, and D. C. Schmitt. I thank the many kind Bolivians who allowed me to work on their land. Without their gracious hospitality, this study would not have been possible. M. Isler and P. Isler provided invaluable assistance with the sampling design. S. Rohwer provided guidance on methods of specimen preparation. I thank J. V. Remsen for pointing out the Variable Antshrike when I was searching for a highly polymorphic Andean species to study. I thank S. Edwards, J. Gasper, and the rest of the Edwards lab for assistance with laboratory protocols, data analysis, and for a fun working environment. N. Crochet helped with sequencing at LSU. M. Carling, Z. Cheviron, M. Isler, P. Isler, J. V. Remsen, Jr., and two anonymous reviewers provided valuable comments on the manuscript. The research was supported by National Science Foundation grant DBI-9974235 and by a Coypu Foundation Grant. ANALYSE software by N. H. Barton and S. J. E. Baird is available at helios.bto.ed.ac.uk/evolgen/ Mac/Analyse/index.html. MIGRATE software by P. Beerli is available at evolution.genetics.washin gton.edu/lamarc.html.

\section{Literature Cited}

Aleixo, A. 2002a. Molecular systematics and the role of the "várzea"-"terra-firme" ecotone in the diversification of Xiphorhynchus woodcreepers (Aves: Dendrocolaptidae). Auk 119:621-640.

Aleixo, A. 2002b. Molecular systematics, phylogeography, and population genetics of Xiphorhynchus (Aves: Dendrocolaptidae) in the Amazon basin. Ph.D. dissertation, Louisiana State University, Baton Rouge.

Barton, N. H., and K. S. Gale. 1993. Genetic analysis of hybrid zones. Pages 13-45 in Hybrid Zones and the Evolutionary Process (R. G. Harrison, Ed.). Oxford University Press, New York.

Bates, J. M. 2000. Allozymic genetic structure and natural habitat fragmentation: Data for five species of Amazonian forest birds. Condor 102:770-783.

BAtes, J. M. 2002. The genetic effects of forest fragmentation on five species of Amazonian birds. Journal of Avian Biology 33:276-294.

Bates, J. M., S. J. Hackett, and J. M. Goerck. 1999. High levels of mitochondrial DNA differentiation in two lineages of antbirds (Drymophila and Hypocnemis). Auk 116: 1093-1106.

Bates, J. M., J. G. Tello, and J. M. C. Silva. 2003. Initial assessment of genetic diversity in ten bird species of South American cerrado. Studies on Neotropical Fauna and Environment 38:87-94.

Beerli, P., And J. Felsenstein. 2001. Maximum likelihood estimation of a migration matrix and effective population sizes in $n$ subpopulations by using a coalescent approach. Proceedings of the National Academy of Sciences USA 98:4563-4568.

Bond, J., And R. Meyer de Schauensee. 1942. The birds of Bolivia. Part I. Proceedings of the Academy of Natural Sciences of Philadelphia 94:307-391.

Brumfield, R. T., and A. P. Capparella. 1996. Historical diversification of birds in northwestern South America: A molecular perspective on the role of vicariant events. Evolution 50:1607-1624.

Brumfield, R. T., R. W. Jernigan, D. B. McDonald, And M. J. Braun. 2001. Evolutionary implications of divergent clines in an avian (Manacus: Aves) hybrid zone. Evolution 55:2070-2087.

Brumfield, R. T., O. Maillard Z., R. C. Faucett, G. Sánchez, V. G. Rohwer, J. C. Catari, C. G. Schmitt, D. C. Schmitt, R. Strem, and A. M. Mamani. 2004. Birds of the Laguna Kaucaya area, a semi-humid valley in the Andean foothills of departamento Santa Cruz, Bolivia. Ornitologia Neotropical 15:381-398.

Capparella, A. P. 1988. Genetic variation in Neotropical birds: Implications for the speciation process. Pages 1658-1664 in Acta XIX Congressus Internationalis Ornithologici (H. Ouellet, Ed.). University of Ottawa Press, Ottawa.

Capparella, A. P. 1991. Neotropical avian diversity and riverine barriers. Pages 307-316 in Proceedings 20th International Ornithological Congress (B. D. Bell, Ed.). 
Congressional Trust Board, Wellington, New Zealand.

Clement, M., D. Posada, and K. A. Crandall. 2000. TCS: A computer program to estimate gene genealogies. Molecular Ecology 9: 1657-1660.

Cory, C. B., and C. E. Hellmayr. 1924. Catalogue of Birds of the Americas. Field Musuem of Natural History Publications, Zoological Series, vol. 13, part 3.

Darrieu, C. A. 1997. Revisión sistemática de las subespecies de Thamnophilus caerulescens Vieillot de la República Argentina (Aves, Formicariidae). Physis, Sección C 54:19-25.

Darrieu, C. A., ANd A. R. Camperi. 1990. Study of the birds collected by W. H. Partridge in Corrientes Province Argentina I. Hornero 13:138-146.

Desjardins, P., And R. Morais. 1990. Sequence and gene organization of the chicken mitochondrial genome. A novel gene order in higher vertebrates. Journal of Molecular Biology 212:599-634.

Fleischer, R. C., C. E. McIntosh, and C. L. Tarr. 1998. Evolution on a volcanic conveyor belt: Using phylogeographic reconstructions and K-Ar-based ages of the Hawaiian Islands to estimate molecular evolutionary rates. Molecular Ecology 7:533-545.

García, N. O. 1994. South American climatology. Quaternary International 21:7-27.

García-Moreno, J., P. Arctander, And J. FJELDSÅ. 1999. A case of rapid diversification in the Neotropics: Phylogenetic relationships among Cranioleuca spinetails (Aves, Furnariidae). Molecular Phylogenetics and Evolution 12:273-281.

García-Moreno, J., and J. FJeldså. 1999. Reevaluation of species limits in the genus Atlapetes based on mtDNA sequence data. Ibis 141:199-207.

García-Moreno, J., J. Ohlson, and J. Fjeldså. 2001. MtDNA sequences support monophyly of Hemispingus tanagers. Molecular Phylogenetics and Evolution 21:424-435.

Graham, A., K. M. Gregory-Wodzicki, and K. L. Wright. 2001. Studies in Neotropical botany. XV. A Mio-Pliocene palynoflora from the eastern Cordillera, Bolivia: Implications for the uplift history of the Central Andes. American Journal of Botany 88:1545-1557.

Gregory-Wodzicki, K. M. 2000. Uplift history of the central and northern Andes: A review. Bulletin of the Geological Society of America 112:1091-1105.

Наскетт, S. J. 1996. Molecular phylogenetics and biogeography of tanagers in the genus Ramphocelus (Aves). Molecular Phylogenetics and Evolution 5:368-382.

Haldane, J. B. S. 1922. Sex ratio and unisexual sterility in animal hybrids. Journal of Genetics 12:101-109.

Harpending, R. C. 1994. Signature of population growth in a low resolution mitochondrial DNA mismatch distribution. Human Biology 66:591-600.

Hasegawa, M., H. Kishino, and T. Yano. 1985. Dating of the human-ape splitting by a molecular clock of mitochondrial DNA. Journal of Molecular Evolution 21:160-174.

Hastings, W. K. 1970. Monte Carlo sampling methods using Markov chains and their applications. Biometrika 57:97-109.

Herzog, S. K., And M. Kessler. 2002. Biogeography and composition of dry forest bird communities in Bolivia. Journal für Ornithologie 143:171-204.

Herzog, S. K., M. Kessler, S. Maijer, and S. Hohnwald. 1997. Distributional notes on birds of Andean dry forests in Bolivia. Bulletin of the British Ornithologists' Club 117:223-235.

Hewitt, G. M. 1988. Hybrid zones-Natural laboratories for evolutionary studies. Trends in Ecology and Evolution 3:158-167.

Higgins, D. G., And P. M. Sharp. 1988. CLUSTAL: A package for performing multiple sequence alignment on a microcomputer. Gene 73: 237-244.

Isler, M. L., P. R. Isler, and R. T. Brumfield. 2005. Clinal variation in vocalizations of an antbird (Thamnophilidae) and implications for defining species limits. Auk 122:433-444.

Isler, M. L., P. R. Isler, ANd B. M. Whitney. 1998. Use of vocalizations to establish species limits in antbirds (Passeriformes: Thamnophilidae). Auk 115:577-590.

KEY, K. H. L. 1968. The concept of stasipatric speciation. Systematic Zoology 17:14-22.

Killeen, T. J., E. Garcia, and S. G. Beck. 1993. Guia de Arboles de Bolivia. Herbario Nacional de Bolivia, La Paz, Bolivia and Missouri Botanical Garden, St. Louis, Missouri.

Kocher, T. D., W. K. Thomas, A. Meyer, S. V. Edwards, S. P̈̈̈̈во, F. X. Villablanca, AND 
A. C. Wilson. 1989. Dynamics of mitochondrial DNA evolution in mammals: Amplification and sequencing with conserved primers. Proceedings of the National Academy of Sciences USA 86:6196-6200.

Kratter, A. W., T. S. Sillett, R. T. Chesser, J. P. O’Neill, T. A. Parker III, and A. Castillo. 1993. Avifauna of a Chaco locality in Bolivia. Wilson Bulletin 105:114-141.

LANDE, R. 1981. Models of speciation by sexual selection on polygenic traits. Proceedings of the National Academy of Sciences USA 78: 3721-3725.

Marks, B. D., S. J. Hackett, and A. P. Capparella. 2002. Historical relationships among Neotropical lowland forest areas of endemism as inferred from mitochondrial DNA sequence variation in the Wedgebilled Woodcreeper (Dendrocolaptidae: Glyphorynchus spirurus). Molecular Phylogenetics and Evolution 24:155-167.

May, R. M., J. A. Endler, and R. E. McMurtrie. 1975. Gene frequency clines in the presence of selection opposed by gene flow. American Naturalist 109:659-676.

Mayer, S. 2000. Birds observed in and near the reserve of Tariquia, dpto. Tarija, Bolivia, in September/October 1992. [Online.] Available at www.bolivianbeauty.com/ Tariquia/MainPage.htm.

Mayer, S., M. B. Christiansen, and E. Pitter. 2000. Birds observed along the road Vallegrande-Masicurí, dpto. Santa Cruz, Bolivia, in 1991-3. [Online.] Available at www.bolivianbeauty.com/VallegrandeMasicuri/MainPage.htm.

MAYr, E. 1942. Systematics and the Origin of Species. Columbia University Press, New York.

Metropolis, N., A. W. Rosenbluth, M. N. Rosenbluth, A. H. Teller, and E. Teller. 1953. Equations of state calculations by fast computing machines. Journal of Chemical Physics 21:1087-1092.

Moore, W. S. 1977. An evaluation of narrow hybrid zones in vertebrates. Quarterly Review of Biology 52:263-277.

Moore, W. S., AND J. T. Price. 1993. Nature of selection in the Northern Flicker hybrid zone and its implications for speciation theory. Pages 196-225 in Hybrid Zones and the Evolutionary Process (R. G. Harrison, Ed.). Oxford University Press, New York.
Navarro, A., and N. H. Barton. 2003. Accumulating postzygotic isolation genes in parapatry: A new twist on chromosomal speciation. Evolution 57:447-459.

Navarro, G. 2002. Provincia biogeográfica del chaco boreal. Pages 195-240 in Geografía Ecológica de Bolivia; Vegetación y Ambientes Acuáticos (G. Navarro and M. Maldonado, Eds.). Fundación Simón I. Patiño, Cochabamba, Bolivia.

Noor, M. A. F. 1999. Reinforcement and other consequences of sympatry. Heredity 83: 503-508.

Pamilo, P., and M. Nei. 1988. Relationships between gene trees and species trees. Molecular Biology and Evolution 5:568-583.

Parker, T. A. I., A. H. Gentry, R. B. Foster, L. H. Emmons, and J. V. Remsen, Jr. 1993. The Lowland Dry Forests of Santa Cruz, Bolivia: A Global Conservation Priority. Conservation International, Washington, D.C.

Parsons, T. J., S. L. Olson, and M. J. Braun. 1993. Unidirectional spread of secondary sexual plumage traits across an avian hybrid zone. Science 260:1643-1646.

Paynter, R. A. J. 1992. Ornithological Gazetteer of Bolivia, 2nd ed. Museum of Comparative Zoology, Cambridge, Massachusetts.

Peters, J. L. 1951. Check-list of Birds of the World, vol. 7. Museum of Comparative Zoology, Cambridge, Massachusetts.

Posada, D., ANd K. A. Crandall. 1998. MODELTEST: Testing the model of DNA substitution. Bioinformatics 14:817-818.

Ramos-Onsins, S. E., AND J. Rozas. 2002. Statistical properties of new neutrality tests against population growth. Molecular Biology and Evolution 19:2092-2100.

Remsen, J. V., JR., And M. A. Traylor, Jr. 1989. An Annotated List of the Birds of Bolivia. Buteo Books, Vermillion, South Dakota.

Ridgely, R. S., and G. Tudor. 1994. The Birds of South America, vol. 2: The Suboscine Passerines. University of Texas Press, Austin.

Rivera, M. O., S. Libermann, and S. Beck. 1996. Vegetacion de Bolivia. Pages 169-222 in Comunidades Territories Indigenas y Biodiversidad en Bolivia (K. Mihotek, Ed.). Centro de Investigación y Manejo de Recursos Naturales Renovables, Santa Cruz, Bolivia. 
Rozas, J., AND R. Rozas. 1999. DNASP, version 3: An integrated program for molecular population genetics and molecular evolution analysis. Bioinformatics 15:174-175.

Saitou, N., and M. Nei. 1987. The neighborjoining method: A new method for reconstructing phylogenetic trees. Molecular Biology and Evolution 4:406-425.

Schmitt, C. G., D. C. Schmitt, and J. V. Remsen, JR. 1997. Birds of the Tambo area, an arid valley in the Bolivian Andes. Pages 701-716 in Studies in Neotropical Ornithology Honoring Ted Parker (J. V. Remsen, Jr., Ed.). Ornithological Monographs, no. 48.

Schneider, C. J., T. B. Smith, B. Larison, And C. Moritz. 1999. A test of alternative models of diversification in tropical rainforests: Ecological gradients vs. rainforest refugia. Proceedings of the National Academy of Sciences USA 96:13869-13873.

Schneider, S., D. Roessli, ANd L. Excoffier. 2000. ARLEQUIN: A software for population genetics data analysis, version 2.000. Genetics and Biometry Lab, Department of Anthropology, University of Geneva, Geneva.

Schulenberg, T. S., And K. Awbrey, Eds. 1998. A Rapid Assessment of the Humid Forests of South Central Chuquisaca, Bolivia. University of Chicago Press, Chicago.

Shields, G. F., AND A. C. Wilson. 1987. Calibration of mitochondrial DNA evolution in geese. Journal of Molecular Evolution 24: 212-217.

SHorT, L. L. 1975. A zoogeographic analysis of the South American chaco avifauna. Bulletin of the American Museum of Natural History 154:163-352.

Silva, J. M. C. 1995. Biogeographic analysis of the South American Cerrado avifauna. Steenstrupia 21:49-67.

Smith, T. B., C. J. Schneider, And K. Holder.

\section{ApPendix}

Burke Museum of Natural History tissue cata$\log$ numbers for the specimens of T. caerulescens analyzed in the present study: T. c. aspersiventer (A1): RTB396-409, RTB410-415; T. c. connectens (C1): RTB440-457; T. c. connectens (C2): RTB314, RTB320, RTB322-325, RTB328-332, RTB431432, RTB436-439; T. c. dinellii (D1): RTB511,
2001. Refugial isolation versus ecological gradients: Testing alternative mechanisms of evolutionary divergence in four rainforest vertebrates. Genetica 112:383-398.

Smith, T. B., R. K. Wayne, D. J. Girman, and M. J. BRuford. 1997. A role for ecotones in generating rainforest biodiversity. Science 276:1855-1857.

Swofford, D. L. 1998. PAUP* (*And Other Methods). Sinauer Associates, Sunderland, Massachusetts.

Szymura, J. M., And N. H. Barton. 1986. Genetic analysis of a hybrid zone between the fire-bellied toads, Bombina bombina and $B$. variegata, near Cracow in southern Poland. Evolution 40:1141-1159.

Szymura, J. M., and N. H. Barton. 1991. The genetic structure of the hybrid zone between the fire-bellied toads Bombina bombina and B. variegata: Comparisons between transects and between loci. Evolution 45:237-261.

Tajima, F. 1989. Statistical method for testing the neutral mutation hypothesis by DNA polymorphism. Genetics 123:585-595.

Watterson, G. A. 1975. On the number of segregating sites in genetical models without recombination. Theoretical Population Biology 7:256-276.

Zimmer, K. J., And M. L. Isler. 2003. Family Thamnophilidae (Typical Antbirds). Pages 448-681 in Handbook of the Birds of the World, vol. 8: Broadbills to Tapaculos (J. del Hoyo, A. Elliott, and D. Christie, Eds.). Lynx Edicions, Barcelona, Spain.

Zink, R. M., And J. V. Remsen, JR. 1986. Evolutionary processes and patterns of geographic variation in birds. Pages 1-69 in Current Ornithology, vol. 4 (R. F. Johnston, Ed.). Plenum Press, New York.

Associate Editor: R. M. Zink

RTB513-514, RTB525, RTB527, RTB536, RTB539, RCF2145, RCF-2148; T. c. dinellii (D2): DCS5320, DCS5334, RTB340-341, RTB344-346, RTB348; T. c. dinellii (D3): RTB540-547, RTB549-550, VGR215, VGR225; T. c. dinellii (D4): RTB561565, RCF2164-2166, RCF2168, VGR295-298; T. c. paraguayensis (P1): RTB362, DCS5408, DCS5409, AMS236-237, MJB859-860, RTB365-380; T. c. paraguayensis (P2): RTB381-388. 